The meteorological record for the week ending April 23, in Boston, was as follows, according to observations furnished by Sergeant $\mathrm{O}$. B. Cole, of the United States Signal Corps: -

\begin{tabular}{|c|c|c|c|c|c|c|c|c|c|c|c|c|c|c|c|c|c|c|c|}
\hline \multirow{2}{*}{$\begin{array}{l}\text { Week ending } \\
\text { Saturday, } \\
\text { Apr. } 23,1887 .\end{array}$} & \multirow{2}{*}{\begin{tabular}{c}
$\begin{array}{c}\text { Barom- } \\
\text { eter. }\end{array}$ \\
\multirow{E}{*}{}
\end{tabular}} & \multicolumn{3}{|c|}{ Thermonieter. } & \multicolumn{4}{|c|}{$\begin{array}{c}\text { Relative } \\
\text { Humidity. }\end{array}$} & \multicolumn{3}{|c|}{$\begin{array}{l}\text { Direction of } \\
\text { Wind. }\end{array}$} & \multicolumn{3}{|c|}{$\begin{array}{c}\text { Velocity of } \\
\text { Wind. }\end{array}$} & \multicolumn{3}{|c|}{$\begin{array}{c}\text { State of } \\
\text { Weather. }\end{array}$} & \multicolumn{2}{|c|}{ Kainfall. } \\
\hline & & 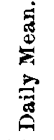 & 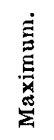 & 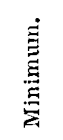 & $\begin{array}{l}\dot{a} \\
\dot{4} \\
\stackrel{0}{0} \\
i\end{array}$ & $\begin{array}{l}\dot{a} \\
\dot{0} \\
\stackrel{8}{0}\end{array}$ & $\begin{array}{l}\dot{a} \\
\dot{2} \\
\dot{0} \\
\dot{1}\end{array}$ & 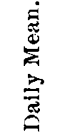 & $\begin{array}{l}\dot{a} \\
\dot{3} \\
\stackrel{8}{8}\end{array}$ & $\begin{array}{l}\dot{8} \\
\dot{0} \\
\dot{8} \\
\dot{\varphi}\end{array}$ & $\begin{array}{l}\dot{a} \\
\dot{2} \\
\dot{8} \\
\dot{q}\end{array}$ & $\begin{array}{l}\dot{8} \\
\dot{4} \\
8 \\
\end{array}$ & $\begin{array}{l}\dot{E} \\
\dot{\alpha} \\
\dot{8}\end{array}$ & $\begin{array}{l}\dot{a} \\
\dot{2} \\
\dot{8} \\
\dot{0}\end{array}$ & $\sum_{i}^{\dot{8}}$ & $\begin{array}{l}\dot{2} \\
\dot{0} \\
\dot{0}\end{array}$ & 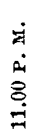 & 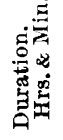 & 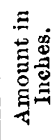 \\
\hline $\begin{array}{l}\text { Sunday,...17 } \\
\text { Monday,..18 } \\
\text { Tuesday,..19 } \\
\text { Wednes,,.20 } \\
\text { Thursday, 21 } \\
\text { Friday, ..22 } \\
\text { Saturday,.23 }\end{array}$ & $\begin{array}{l}29.835 \\
29.818 \\
29.837 \\
30.039 \\
30.106 \\
30.117 \\
29.939\end{array}$ & $\begin{array}{l}39.0 \\
29.0 \\
39.0 \\
48.0 \\
47.0 \\
51.0 \\
50.0\end{array}$ & $\begin{array}{l}48.0 \\
35.0 \\
48.0 \\
56.0 \\
54.0 \\
60.0 \\
59.0\end{array}$ & $\begin{array}{l}34.0 \\
26.0 \\
28.0 \\
34.0 \\
38.0 \\
42.0 \\
46.0\end{array}$ & $\begin{array}{l}69.0 \\
64.0 \\
82.0 \\
51.0 \\
45.0 \\
51.0 \\
50.0\end{array}$ & $\begin{array}{r}43.0 \\
100.0 \\
39.0 \\
35.0 \\
54.0 \\
60.0 \\
57.0\end{array}$ & $\begin{array}{l}41.0 \\
97.0 \\
48.0 \\
47.0 \\
57.0 \\
53.0 \\
94.0\end{array}$ & $\begin{array}{l}51.0 \\
87.0 \\
56.0 \\
44.0 \\
52.0 \\
55.0 \\
67.0\end{array}$ & $\begin{array}{l}\text { N.W. } \\
\text { N. } \\
\text { N. } \\
\text { W. } \\
\text { N.w. } \\
\text { W. } \\
\text { S.W. }\end{array}$ & $\begin{array}{l}\text { N.W. } \\
\text { E. } \\
\text { N. } \\
\text { W. } \\
\text { E. } \\
\text { E. } \\
\text { E. }\end{array}$ & $\begin{array}{l}\text { N.W. } \\
\text { N.w. } \\
\text { N.W. } \\
\text { N.W. } \\
\text { W. } \\
\text { s. } \\
\text { s.E. }\end{array}$ & $\begin{array}{r}24 \\
7 \\
16 \\
8 \\
4 \\
6 \\
2\end{array}$ & $\begin{array}{l}16 \\
16 \\
12 \\
14 \\
12 \\
12 \\
14\end{array}$ & $\begin{array}{r}16 \\
24 \\
11 \\
7 \\
11 \\
4 \\
8\end{array}$ & $\begin{array}{l}0 . \\
0 . \\
0 . \\
\text { C. } \\
\text { c. } \\
\text { C. } \\
\text { C. }\end{array}$ & $\begin{array}{l}\text { C. } \\
\text { N. } \\
\text { C. } \\
\text { C. } \\
\text { C. } \\
\text { c. } \\
\text { T. }\end{array}$ & $\begin{array}{l}\text { C. } \\
\text { R. } \\
\text { C. } \\
\text { c. } \\
\text { c. } \\
\text { C. } \\
\text { R. }\end{array}$ & $\begin{array}{l}\overline{12} \\
\frac{2}{-} \\
\overline{3}\end{array}$ & $\begin{array}{l}\overline{33} \\
02 \\
\overline{-} \\
\overline{.01}\end{array}$ \\
\hline $\begin{array}{l}\text { Mean, the } \\
\text { Week. }\end{array}$ & 29.956 & 43.0 & 51.0 & 35.0 & & & & 59.0 & & & & & & & & & & 17 & .36 \\
\hline
\end{tabular}

OFFICIAL LIST OF CHANGES IN THE STATIONS AND

DUTIES OF OFFICERS SERVING IN THE MEDICAL DE-

PARTMENT, U. S. ARMY, FROM APRIL 23, 1887, TO APRII. $29,1887$.

Smith, J. R., lieutenant colonel and surgeon. By Par. 8, S. O. 92, A. G. O., April 21, 1887. Detailed as member of board to meet in Washington, D. C., April 28, to prepare rules and regulations for the government of the Hospital Corps of the Army.

TAYLOR, Morse K., major and surgeon. Relieved from duty at Fort Sill, I. T., May 10, 1887, to proceed home, San Antonio, Texas, preparatory to retirement. Par. 20, S. O.92, A. G. O., April 21, 1887.

Heizmane, Chas. L., major and surgeon. By Par. 8, S. O. 92, A. G. O., April 21, 1887. Detailed as member of board to meet in Washington, U.C., April 28, to prepare rules and regulations for the government of the Hospital Corps of the Army.

AINsworth, FrED. C., captain and assistant surgeon. By Par. 8, S. O. 92, A. G. O., April 21, 1887. Detailed as member of board to meet in Washington, D.C., April 28, to prepare rules and regulations for the government of the Hospital Corps of the Army.

Cabrel, Julian M., first lieutenant and assistant surgeon (recently appointed). To proceed to Fort Omaha, Nebraska, and report in person to the commanding officer of that post for temporary duty. Par. 19, S. O. 92, A. G. O., April 21, 1887.

Woodruff, Charles E., first lieutenant and assistant surgeon (recently appointed). Ordered for duty at Fort Wayne, Mich. S. O. 96, A. G. O., April 26, 1887.

OFFICLAL LIST OF CHANGES IN THE MEDICAL CORPS OF THE UNITED STATES NAVY DURING THE WEEK ENDING APRIL 30, 1887.

ATLEE, L. W., assistant surgeon. Ordered to the Receiving Ship "Vermont."

Bidder, Clement, passed assistant surgeon. Detached froin the Naval Academy and to Marine Rendezvous, Philadelphia, $\mathrm{Pa}$.

Ashbridge, RICHARD, passed assistant surgeon. Ordered to the Naval Academy.

Hudson, A., medical inspector. Ordered to the United States Steamship “Trenton.'

Hгввет, C. T., passed assistant surgeon. Ordered to the United States Steanship “Trenton."

Decker, Corbin J., assistant surgeon. Detached from the Receiving Ship "St. Louis," and to the United States Steamship "Trenton."

UFFICIAL LIST OF CHANGES OF STATIONS AND DUTIES OF MEDICAL OFFICERS OF THE UNITED STATES MARINE-HOSPITAL SERVICE, FOR THE THREE WEEKS ENDING APRIL, 30, 1887.

Goldsborough, C. B., surgeon. Leave of absence extended thirty days, on account of sickness. April 20, 1887.

Devan, S. C., passed assistant surgeon. Granted leave of absence for thirty days, to take effect when relieved. April 12, 1887.

Bratton, W. D., assistant surgeon. To proceed to Port Townsend, W. T., and assume temporary charge of the service. April 21, 1887.

\section{SOCIETY NOTICES.}

Gynacological Socinty of Boston.- - The next meeting of the Society will be held at the Medical Library Rooms, No. 19 Boylston Place, on Thursday, May 12, at 4 o'clock, P.M. Reader: Dr. H. J. Harriman, "The Relation of Improper Alimentation to the Ill Health of Women."

H. J. Harriman, M.D., Secretary.

Norfolk District Medical Socikty. - The annual meeting will be held at Rockland Hall, No. 2343 Washington Street, Roxbury, Tuesday, May 10, at 2 P.M. The Board of Censors will meet at 1 P.M. Order of business: 1. Readiug of Records. 2. Report of Committees. 3. Election of Officers. 4. Report of Treasurer. 5. Incidental Business. 6. Communications: (a) "The Third Stage of Labor," E. G. Morse, M.D. (b) "A Case of Probable Intussusception with Recovery," E. F. Dunbar, M.D. 7. Introduction of newly-elected Officers.

$$
\text { S. Allen Potter, M.D., Secretary. }
$$

Massachusetts Medical Society, Suffolk District.The Section for Clinical Medicrne, Pathology and HyGIEN w will meet at 19 Boylston Place, on Wednesday, May 11 th, at 7.45 o'clock. Papers: Dr. F. W. Stuart, "Can Cirrhosisfollow Trauma? a Case of Medico-Legal Interest." Dr. F. I. Knight will report "A Case suggesting some Considerations in regard to the Contagiousness of Tubercular Disease of the Lungs." Dr. John S. Billings, of Washington, is expected to be present, and to take part in the discussion.

F. I. Knight, M.D. Albert N. Blodget, M.D., Secretary.

\section{BOSTON CITY HOSPITAL EXAMINATIONS.}

The semi-annual examination of candidates for the position of externe at the Boston City Hospital, will be hèld Wednesday and Thursday afternoons, May 11th and 12th, at the Hospital, at 4 P.M. 160 Boylston St., at Home 1-3 P.M.

\section{DEATH.}

Died in Cohasset, Mass., April 29, 1887, Gustavus Percival Pratt, M.D., M.M.S.S., aged forty-seven years.

\section{BOOKS AND PAMPHLETS RECEIVED.}

The Rhus Glabrum. A Remedy for Stomatitis. By Hiram Corson, of Conshohocken, Pa. 1887. (Reprint.)

Will Contests. By Walter E. Rex, Esq., formerly Register of Wills for the City and County of Philadelphia. 1887.

Cocaine in General Surgery. By John B. Wheeler, M.D., Instructor in Surgery, University of Vermont. Montpelier, Vt., 1887.

Report of the Commission appointed by the Governor of Minnesota to Locate and Prepare Plans for a Third Hospital for the Insane. St. Paul, 1887.

A Successful Case of Partial Excision of the Larynx on account of Intra-Laryngeal Epithelioma. By Lennox Browne, F.R.C.S. Ed. (Reprint.)

Some Considerations concerning Cancer of the Uterus, especially its Palliative Treatment in its Later Stages. By Andrew F. Currier, M.D. 1887. (Reprint) 